\title{
PENYESUAIAN SOSIAL SISWA TUNARUNGU (Studi Kasus di SMK Negeri 30 Jakarta)
}

\author{
Karina Ulfa Zetira ${ }^{1}$ \\ Dra. Atiek Sismiati Subagyo ${ }^{2}$ \\ Dr. Dede Rahmat Hidayat, M.Psi ${ }^{3}$
}

\begin{abstract}
Abstrak
Tujuan dari penelitian ini adalah untuk mengungkap berbagai fakta tentang penyesuaian sosial pada siswa tunarungu di Sekolah Menengah Kejuruan (SMK) Negeri 30 Jakarta. Penelitian ini menggunakan pendekatan kualitatif dengan metode studi kasus. Penelitian dilaksanakan di SMK Negeri 30 Jakarta, dengan dua responden yaitu siswa kelas XI Busana 2 dan XII Boga 3. Responden diambil berdasarkan hasil studi pendahuluan untuk mengetahui terdapat siswa yang memiliki keterbatasan dalam mendengar (tunarungu). Pengumpulan data dilakukan melalui wawancara, observasi dan dokumentasi. Wawancara yang dilakukan adalah wawancara terstruktur terhadap subjek atau kasus, teman sebangku, teman sebaya, wali kelas dan orang tua dengan mengacu pada teori penyesuaian sosial dari Hurlock. Data hasil penelitian dianalisis secara deskriptif kualitatif melalui studi kasus, adapun penyajian data menggunakan narasi. Pemeriksaan keabsahan data dilakukan dengan triangulasi sumber data. Hasil penelitian keseluruhan menunjukan Responden RH memiliki penyesuaian sosial yang rendah. Prilaku sosial yang timbul pada RH lebih banyak diam dan menyendiri dari pada ikut serta bergabung dengan teman-teman lainnya. RH mengaku bahwa ia merasa tidak nyaman berada diantara teman-temannya, RH merasa minder dengan kondisinya sebagai anak tunarungu di sekolah umum. Hal ini karena teman-teman di kelas suka mengejeknya. RH merasa kurang dapat menyesuaikan diri di lingkungan sekolah. Sedangkan responden $R$ memiliki penyesuaian yang cukup tinggi dibandingkan $R H$, perilaku sosial $R$ mampu membangun hubungan yang baik dengan teman-temannya di sekolah, dimana $R$ suka membantu temannya yang sedang mengalami kesulitan, berbagi cerita dengan teman-temannya, berbaur dengan kelompok saat sedang bercanda gurau. Walaupun terkadang $R$ suka merasa minder dengan kondisinya sebagai anak tunarungu di sekolah umum tersebut, namun $R$ selalu berusaha untuk lebih percaya diri. Diketahui bahwa RH dan R merupakan siswa SMKN 30 yang sama-sama berkebutuhan khusus yaitu tuna rungu, mereka memiliki penyesuaian sosial yang berbeda. RH memiliki penyesuaian sosial yang rendah, sedangkan $R$ memiliki penyesuaian sosial yang cukup tinggi.
\end{abstract}

Kata Kunci : Penyesuaian Sosial, Tunarungu

\footnotetext{
Mahasiswa Jurusan Bimbingan dan Konseling FIP UNJ, kartikasari13@gmail.com Dosen Bimbingan dan Konseling FIP UNJ Dosen Bimbingan dan Konseling FIP UNJ
} 


\section{Pendahuluan}

Remaja adalah masa yang penuh gejolak dan penuh dengan berbagai permasalahan. Hal ini terjadi akibat dari ketidak seimbangan pikiran, perasaan, serta kepekaan terhadap rangsangan-rangsangan dari luar. Berbagai macam gejolak pada diri remaja sebenarnya bersumber dari perubahan-perubahan pada dirinya sebagai akibat terjadinya perkembangan fisik, psikologis, emosional, dan sosial.

Penyesuaian sosial adalah usaha pembelajaran bagi individu dalam menyesuaikan diri dengan lingkungan budayanya agar dapat diterima orang lain sesuai dengan norma-norma yang berlaku dalam masyarakat. Individu memiliki penyesuaian sosial yang baik memiliki ciri-ciri antara lain; individu berpenampilan nyata atau sesuai dengan kelompoknya, mampu melakukan penyesuaian diri terhadap kelompok, individu mempunyai kepuasan pribadi dalam menyesuaikan diri secara sosial dengan baik

Dalam kehidupan sehari-hari berinteraksi dan menyesuaikan diri dengan lingkungan sekitarnya merupakan suatu hal yang lazim dan sangat penting dilakukan oleh setiap manusia karena dalam bermasyarakat manusia perlu untuk bersosialisasi. Dalam melakukan penyesuaian diri dan berinteraksi tidak saja hanya mengandalkan kemampuan individu dalam berbicara, tetapi ada aturan-aturan tertentu yang harus dipatuhi sehingga apa yang dibicarakan atau dimaksudkan dapat dimengerti oleh orang lain. Namun tidak semua orang mampu berkomunikasi menggunakan bahasa dengan baik. Banyak faktor yang dapat menyebabkan seseorang tidak dapat menggunakan bahasa dengan baik dan tepat, seperti dikarenakan lingkungan pergaulan, penguasaan terhadap tatanan bahasa yang kurang, ataupun dikarenakan seseorang yang mengalami hambatan pada pendengaran yang dikenal dengan ketunarunguan, terutama bagi mereka yang mengalami ketunarunguan sejak lahir ataupun disebabkan sakit atau kecelakaan saat mereka masih kecil.

Sekolah merupakan tempat anak dan remaja tunarungu belajar berkomunikasi dan bersosialisasi serta mengembangkan potensi yang dimilikinya. Remaja tunarungu akan memerlukan penyesuaian diri yang baru ketika berada dilingkungan yang baru. Permasalahan akan muncul ketika remaja tunarungu bera- da dalam suatu tempat dengan anak regular di sekolah umum. Selama ini, permasalahan yang dialami penderita tunarungu adalah kesulitan dalam melakukan komunikasi. Kesulitan yang dimiliki remaja tunarungu tentu akan lebih susah melakukan penyesuaian diri dan sosial dengan lingkungan biasa yaitu sekolah anak reguler, sehingga remaja tunarungu juga lebih mudah mengalami frustasi dan memiliki kematangan sosial yang rendah.

\section{Kajian Teori}

Menurut Scheineders penyesuaian sosial merupakan suatu kapasitas atau kemampuan yang dimiliki oleh individu untuk dapat bereaksi secara efektif dan bermanfaat terhadap realitas, situasi, dan relasi sosial, sehingga kriteria yang harus dipenuhi dalam kehidupan sosialnya dapat terpenuhi dengan caracara yang dapat diterima dan memuaskan

Dalam kamus lengkap psikologi, penyesuaian sosial adalah penjalinan sosial secara harmonis suatu relasi dengan lingkungan sosial atau dapat diartikan dalam mempelajari pola tingkah laku yang diperlukan atau mengubah kebiasaan yang ada, sedemikian rupa sehingga cocok bagi suatu masyarakat sosial

Menurut Hurlock, penyesuaian sosial berarti keberhasilan seseorang untuk menyesuaikan diri terhadap orang lain pada umumnya, dan sekelompok yang mereka identifikasi pada khususnya

Menurut Hurlock terdapat kriteria yang mempengaruhi penyesuaian sosial, yaitu sebagai berikut :

1) Penampilan nyata, bila prilaku sosial anak seperti yang dinilai (berdasarkan standar kelompok, memenuhi harapan kelompok), maka anak akan menjadi anggota yang dapat diterima oleh kelompok.

2) Penyesuaian diri terhadap berbagai kelompok, anak yang dapat menyesuaikan diri dengan baik terhadap kelompok, baik kelompok teman sebaya maupun kelompok dewasa dan secara sosial dianggap sebagai orang yang dapat menyesuaikan diri dengan baik secara sosial.

3) Sikap sosial, anak harus dapat menunjukan sikap yang menyenangkan kepada orang lain, terhadap partisipasi sosial dan terhadap perannya dalam kelompok sosial, bila ingin dinilai sebagai orang yang dapat menyesuaikan diri dengan baik se- 
cara sosial.

4) Kepuasan pribadi, untuk dapat menyesuaikan diri secara sosial dengan baik, individu harus dapat merasa puas terhadap kontak sosialnya dan terhadap peran yang dimainkannya dalam situasi sosial, baik sebagai pemimpin ataupun anggota.

\section{Metode Penelitian}

Penelitian ini bertujuan untuk mengetahui informasi lebih mendalam tentang gambaran penyesuaian sosial pada siswa tunarungu, sehingga mereka bisa menyesuaikan diri dalam bersosialisasi dengan baik dan mengetahui kendala yang dihadapi siswa dalam melakukan penyesuaian sosial dengan melihat latar belakang kondisi siswa yang saat ini memiliki keterbatasan dalam mendengar (tunarungu) di SMK Negeri 30 Jakarta.

Penelitian ini dilaksanakan di SMK Negeri 30 Jakarta. Penelitian ini dilaksanakan pada bulan Januari 2013 sampai dengan bulan Maret 2014, dengan rincian sebagai berikut :

\section{Pencarian dan penyaringan responden}

Peneliti melakukan pencarian responden pada bulan Februari, peneliti memilih siswa yang memiliki keterbatasan dalam mendengar (tunarungu) dengan mengajukan permohonan atas kesediaan calon responden untuk bersedia dijadikan responden dalam penelitian ini. Konfirmasi tujuan penelitian kepada dua responden siswa kelas XI dan siswa kelas XII yang memiliki ketunarunguan

2. Proses wawancara dan observasi yang dilakukan Wawancara dan observasi dilakukan pada bulan Mei 2013 hingga Desember 2013 dengan menggunakan pedoman yang digunakan oleh peneliti sesuai dengan kebutuhan penelitian.

3. Analisa data

Pengolahan data hasil wawancara, observasi dan studi dokumentasi akan diolah peneliti pada bulan Desember 2013

Penelitian ini menggunakan pendekatan kualitatif dengan metode studi kasus yang bermaksud untuk memperoleh pemahaman yang utuh dan menyeluruh mengenai penyesuaian sosial pada siswa tunarungu kelas XI dan XII SMK Negeri 30 Jakarta. Penelitian ini menggunakan pendekatan kualitatif, yaitu penelitian yang bermaksud un- tuk memahami fenomena tentang apa yang dialami oleh subjek penelitian misalnya prilaku, persepsi, motivasi, tindakan, dan lain-lain dengan cara holistic atau menyeluruh dan cara deskripsi dalam bentuk kata-kata dan bahasa. Deskripsi yang dimaksud adalah bentuk kata-kata dan bahasa pada konteks khusus alamiah dan dengan memanfaatkan berbagai metode alamiah.

\section{Hasil dan Pembahasan}

\section{Penyesuaian sosial pada responden I (RH)}

Dari hasil wawancara yang dilakukan oleh peneliti kepada RH dapat dilihat secara keseluruhan, responden memiliki penyesuaian sosial yang rendah. prilaku sosial responden tidak berdasarkan standar kelompok dan belum memenuhi harapan kelompok, terlihat responden lebih banyak diam dan menyendiri dari pada ikut serta bergabung dengan teman-teman lainnya. RH mengaku bahwa ia merasa tidak nyaman berada diantara teman-temannya, $\mathrm{RH}$ merasa minder dengan kondisinya sebagai anak tunarungu yang bersekolah disekolah umum. Hal ini karena teman-teman dikelas suka mengejeknya.

Secara sosial RH belum dapat menyesuaikan diri dengan baik terhadap kelompok, baik kelompok teman sebaya maupun kelompok dewasa, terlihat dari sikap RH yang merasa canggung, malu, dan takut ketika RH sedang berhadapan dengan kelompok dewasa yang berada dilingkungan sekolah yaitu kakak kelas.

RH merasa minder dengan kekurangan yang ia miliki dan sikap teman-teman yang seringkali mengejeknya membuat RH lebih banyak bersikap diam dan menyendiri. RH suka merasa marah dan sedih ketika teman-teman sudah mulai memancing kemarahan RH dengan mengejek-ejek RH.RH mengikuti kegiatan ektrakulikuler di sekolah, namun RH kurang berpartisipasi aktif dalam kegiatan tersebut.RH merasa kurang dapat menyesuaiakan diri dilingkungan sekolah.Secara sosial RH belum menunjukan sikap yang menyenangkan kepada orang lain, terhadap partisipasi sosial dan terhadap perannya dalam kelompok sosial

RH belum merasa puas terhadap kontak sosialnya dan terhadap peran yang dimainkannya dalam situasi sosial, terlihat tidak merasa berarti diantara teman-temannya didalam kelas, tidak mudah mengek- 
spresikan perasaannya dihaapan teman-teman, dan merasa bahwa teman-teman tidak ada yang perduli dan menghargainya.

Dari hasil wawancara dengan teman sebangku dan teman yang juga satu kelas dengan responden. Dapat diketahui bahwa $\mathrm{R}$ merupakan anak yang pendiam.

\section{Penyesuaian sosial pada responden II (R)}

Dari wawancara yang dilakukan peneliti kepada $\mathrm{R}$ dapat dilihat secara keseluruhan, responden memiliki penyesuaian sosial yang baik walaupun $\mathrm{R}$ memiliki kekurangan sebagai anak tunarungu. dapat terlihat dari penyesuaian sosial pada karakteristik penampilan nyata, prilaku sosial $\mathrm{R}$ sudah berdasarkan standar kelompok dan memenuhi harapan kelompok, $\mathrm{R}$ dapat membangun hubungan yang baik dengan teman-temannya di sekolah, dimana $\mathrm{R}$ suka membantu temannya yang sedang mengalami kesulitan, berbagi cerita dengan teman-temannya, merasa nyaman berada diantara teman-temannya, berbaur dengan kelompok saat sedang bercanda gurau, segera mengintropeksi dirinya apabila ada yang memberikan kritik kepadanya. Walaupun terkadang $\mathrm{R}$ suka merasa minder dengan kondisinya sebagai anak tunarungu disekolah umum tersebut, namun $\mathrm{R}$ selalu berusaha untuk lebih percaya diri di hadapan teman-temannya dan lingkungan sekolah.

$\mathrm{R}$ sudah dapat menyesuaikan diri dengan baik terhadap kelompoknya, baik didalam kelompok teman sebaya maupun kelompok dewasa.R memiliki teman dekat di sekolah, R akan segera intropeksi diri dan meminta maaf ketika temannya sedang marah dan berubah sikap terhadapnya, $\mathrm{R}$ merasa mudah dalam menyesuaikan dirinya di sekolah, $\mathrm{R}$ juga bergaul dengan kelompok yang lebih dewasa di sekolah yaitu kakak kelas.

Kriteria sikap sosial pada responden II yaitu $\mathrm{R}$ sudah dapat menunjukan sikap yang menyenangkan kepada orang lain, terhadap partisipasi sosial dan terhadap perannya dalam kelompok sosial. Dapat di lihat dimana $\mathrm{R}$ bersikap ramah terhadap orangorang yang ada dilingkungan sekolah serta berpartisipasi aktif dalam kegiatan ektrakulikuler di sekolah.

Secara keseluruhan pada karakteristik kepuasan pribadi, R sudah dapat menyesuaikan diri secara so- sial dengan baik dan $\mathrm{R}$ merasa puas terhadap kontak sosialnya dan terhadap peran yang dimainkannya dalam situasi sosial sebagai anggota di kelasnya. $R$ merasa dirinya berarti saat ia berada diantara teman-temannya di kelas, $\mathrm{R}$ merasa selama ini mudah dalam mengekspresikan perasaanya dihadapan teman-teman, dan R suka mendapatkan bantuan dari teman-temannya ketika ia sedang mengalami kesulitan dalam belajar. $\mathrm{R}$ merasa bahwa orang-orang dilingkungan sekolah semua perduli dan memperhatikannya.

\section{Kesimpulan dan Saran \\ Kesimpulan}

Berdasarkan penelitian yang telah dilakukan, ada beberapa hal yang dapat dipelajar dan dikaji mengenai penyesuaian sosial pada siswa tunarungu di sekolah umum SMKN 30 Jakarta. Diketahui bahwa RH dan R merupakan siswa SMKN 30 yang samasama berkebutuhan khusus yaitu tunarungu, mereka memiliki penyesuaian sosial yang berbeda. $\mathrm{RH}$ memiliki penyesuaian sosial rendah yang membuat RH menarik dirinya dari lingkungan sosial, merasa dikucilkan, dan mendapatkan prilaku bullying dari teman-temannya. $\mathrm{R}$ memiliki penyesuaian sosial yang cukup tinggi, dimana $\mathrm{R}$ mendapatkan penerimaan sosial yang baik dari teman-teman sebayanya, $R$ terlihat lebih percaya diri, dan merasa puas terhadap peran yang dimainkannya dalam situasi sosial di sekolah.

Diketahui bahwa dengan berkembangnya dunia pendidikan anak tuna rungu dapat mengembangkan potensi yang ada pada dirinya dengan melakukan berbagai hal, dan salah satunya adalah mengembangkan proses berkomunikasi dan melakukan penyesuaian diri dan sosial.

Sekolah merupakan tempat anak dan remaja tuna rungu belajar berkomunikasi dan bersosialisasi serta mengembangkan potensi yang dimilikinya. Siswa tuna rungu juga berhak untuk mendapatkan pendidikan akademis dan sosial yang setara dengan siswa normal yang juga bersekolah disekolah umum. Dengan demikian pihak sekolah terutama guru dikelas dapat mengelola dan menentukan strategi dan metode pembelajaran, bahan ajar, perlakuan, dan pengelolaan kelas yang diterapkan harus menyentuh kebutuhan anak tunarungu, sehingga mereka (tu- 
narungu) bisa merasakan layanan pendidikan yang representative di sekolah umum, yang bisa mengantar mereka mencapai tujuan pembelajaran dan penyesuaian sosial secara optimal.

\section{Saran}

Saran yang dapat diberikan berdasarkan hasil penelitian ini bagi berbagai pihak, yaitu :

\section{Bagi Sekolah}

Sekolah inklusi merupakan tempat bagi siswa berkebutuhan khusus (Tunarungu) belajar berkomunikasi dan bersosialisasi serta mengembangkan potensi yang dimilikinya. Oleh karena itu, sebaiknya ditunjang dengan sarana prasarana yang baik serta guru pendamping khusus yang benar benar menguasai dan memiliki keahlian serta keterampilan didalam menangani anak yang berkebutuhan khusus, sehingga tidak terbentur permasalahan dan tidak bingung sendiri dengan apa yang dihadapi.

\section{Bagi Guru}

Seorang pendidik hendaknya mengetahui program pembelajaran yang sesuai bagi anak berkebutuhan khusus. Pola pembelajaran yang harus disesuaikan dengan anak berkebutuhan khusus biasa disebut dengan Individualized Education Program (IEP) atau Program Pembelajaran Individual (PPI). Perbedaan karakteristik yang dimi-liki anak berkebutuhan khusus membuat pendidikan harus memiliki kemampuan khusus. Sebelum Program Pembelajaran Individual dijalankan oleh pendidik, terlebih dahulu pendidik harus melakukan identifikasi terhadap kondisi dan kebutuhan anak berkebutuhan khusus agar diperoleh informasi yang akurat mengenai kebutuhan pembelajaran anak berkebutuhan khusus. Setelah proses skrining atau assesment dilaku- kan dan kebutuhan anak berkebutuhan khusus teridentifikasi, maka Program Pembelajaran Individual (PPI) dapat dijalankan di kelas-kelas reguler.

\section{Bagi Guru BK}

Bimbingan konseling bagi siswa tunarungu merupakan pemberian bantuan pada individu maupun kelompok agar siswa mampu untuk mandiri, seperti dalam hal berkomunikasi dan menyesuaikan dirinya. Oleh karena itu, guru BK di sekolah dapat memberikan layanan konseling individu ataupun layanan konseling kelompok kepada anak berekebutuhan khusus dan siswa normal lainnya, sehingga siswa dapat mengembangkan dirinya secara optimal dan mandiri.

\section{Daftar Pustaka}

Santrock, John W. 2003. Adolescence: Perkembangan Remaja. Jakarta: Erlangga.

Hurlock, Elizabeth. 2002. Psikologi Perkembangan. Jakarta:Erlangga

Hendriarti Agustiani. 2006. Psikologi perkembangan (pendekatan ekologi kaitannya dengan konsep diri dan penyesuaian diri pada remaja). Bandung: Refika Aditama

Asep Supena dan Murni Winarsih, 2012. Pendidikan Anak Berkebutuhan Khusus. Jakarta: 28 Jaya Printing\&Publisher

C.P. Chaplin. 2002. Kamus lengkap psikologi. Jakarta : PT.Grafindo Persada

Lexy J. Moleong. 2005. Metodelogi Penelitian Kualitatif edisi revisi Bandung : PT Remaja Rosdakarya

Sugiyono, 2008. Memahami penelitian kualitatif . Bandung: Alfabet. ,2010. Metode Penelitian Kuantitatif, Kualitatif dan R\&D . Jakarta:Alfabeta

2012 Metode Penelitian Pendidikan . Bandung: Alfabeta2012. 